\title{
Improving Forest Fire Mitigation in Indonesia: A Lesson from Canada
}

\section{Bayu Rizky Prayoga ${ }^{1}$}

School of Environmental Science, Universitas Indonesia, Jakarta, Indonesia

\section{Raldi Hendro Koestoer}

School of Environmental Science, Universitas Indonesia, Jakarta, Indonesia

\author{
Received : 22 June 2021 \\ Accepted : 22 November 2021
}

Available Online : 31 December 2021

\begin{abstract}
Forest fire is a hydrometeorological disaster that routinely occurs in Indonesia every dry season and often hits areas with extensive peatland cover. The lack of scientific references explaining peatlands' physical parameters and their relationship to hotspots' occurrence also contributes to the government intervention's ineffectiveness in forest fires suppression because they are mainly executed in severe drought conditions. Strengthening mitigation, especially at the preparedness stage, is needed to detect forest fires earlier, prevent not from spreading widely, and not cause many environmental, social, and economic losses. This study aims to explain the gaps in forest fire disaster management in Indonesia, which have not maximized the results of observations from physical land and weather conditions as a basis for making decisions for more preventive forest fire mitigation. This study's analysis is conducted using literature studies method from several reports, scientific articles, and regulations related to forest fires. This study's analysis results explain how physical land monitoring and observation can provide a scientific basis that can be used as input in formulating policies, especially regarding the determination of disaster status on forest fire phenomena. Furthermore, this study explains how a paradigm shift in forest fire disaster management is needed in Indonesia through a more preventive approach to implement forest fire disaster mitigation can be more effective and efficient.
\end{abstract}

Keywords: forest fire; mitigation; peatland; policy; prepardness

\section{Introduction}

Forest fires often regularly occur in Indonesia, especially in the dry period. The study conducted by Field et al. (2016) revealed that in the last three decades, forest fires in Indonesia had become increasingly concerning. Sumatra and Kalimantan are regions in Indonesia that regularly contribute carbon emissions and toxic gases from forest and forest fires smoke. Forest fires, which are hydrometeorological disasters, often hit provinces with extensive peatland covers, such as Riau, Jambi, and South Sumatra on Sumatra Island, as well as West Kalimantan, Central Kalimantan, South Kalimantan and East Kalimantan on Kalimantan Island (Huijnen et al., 2016). Deforestation that occurs from burning peat forests contributes to $15 \%$ of the world's greenhouse gas emissions. As one of the largest

\footnotetext{
${ }^{1}$ Corresponding Author: School of Environmental Science, Universitas Indonesia, Jakarta, Indonesia

Email: m.bayu01@ui.ac.id
} 
tropical forest countries globally, Indonesia has removed 1.13 hectares of forest every year (2009-2013 period) or the equivalent of 3 times the size of a football field per minute. While there is good news with deforestation rates decreasing, the numbers are still high. That condition states deforestation, especially in peatland, to be one of the leading causes of greenhouse gas emissions in Indonesia (Palmer, 2001; Austin et al., 2019).

Forest fire suppression in Indonesia has always been massively carried out by the government almost every year. However, unfortunately, the timeliness of implementation of forest fire suppression activities is often considered too late. The poor disaster management in handling forest fire explained by Wibowo (2019) includes at least three factors: the lack of prevention-oriented technological innovation, the complexity of coordination between institutions, and the limited infrastructure that is oriented towards prevention and community economic empowerment. More broadly, the implementation of forest fire disaster mitigation in Indonesia has so far been seen as less than optimal. The occurrence of the forest fire that keeps repeating every year is an indication of that. Therefore, it is essential to further increase awareness of forest fire disaster mitigation by early detection of variables that indicate the potential for forest fires (Faturahman, 2017; Syaufina, 2018; Taufik et al., 2019).

As described in Government Regulation (PP) 21/2008, the implementation of disaster management explains that the authority to administer disaster management in emergency response situations is the National Disaster Management Authority (BNPB). In relation to the disaster chain of command, Perka BNPB 10/2008, concerning Guidelines for Disaster Emergency Response Command, describes the stages of determining disaster status and the flow of command for disaster management in which each regional head (Governor) is responsible for the disaster status of each province. Unfortunately, in some cases of determining the disaster status of forest and land fires at the provincial level, the variables and physical parameters used in determining the disaster status still refer to values at the peak of the dry season. This becomes one reason for the delay and ineffective forest fire suppression, especially during the peak of the dry season, when the escalation of hotspots will reach its peak.

Forest fire suppression activities carried out by land or by air, such as water bombing and the application of weather modification technology, often experience problems because they are carried out during the peak of the dry season. This becomes a problem, especially when looking at peat characteristics, which is prone to the peat smouldering phenomenon, resulting in the detection of hotspots and their extinguishing. The smouldering combustion of peat is a fire phenomenon in peatlands that can occur below the surface so that the spread of fire is complicated to detect. It was further explained that peat smouldering is combustion that occurs in slow, low-temperature, porous fuels without a fire on the surface and the most persistent type of combustion phenomenon (Cochrane, 2015; Rein, 2016).

Canada is an example of a country that has succeeded in mainstreaming variables and physical parameters of land as a reference for forest fire disaster management. With forest cover reaching 300 million hectares, Canada is also experiencing a similar problem in deforestation, namely forest fires. In fact, the long history of forest fires has now succeeded in encouraging Canada to carry out various developments in the concept of forest fire disaster mitigation. The study conducted by Tymstra et al. (2020) can help explain how Canada has succeeded in developing early detection through observations of various physical variables so that it can contribute to improving fire disaster mitigation in the country that prioritizes preventive elements. Several previous studies have focused on technical and modeling to determine the level of vulnerability to forest fires (Syaufina, 2018; Taufik et al., 2019). This research focuses on studies on the use of physical monitoring results and peatlands to be further implemented to mitigate forest fire disasters 
through comparisons with other countries such as Canada. By taking lessons in forest fire disaster management in other country such as Canada, therefore, this paper intends to explain that the importance of early detection is one of the keys to improving forest fire disaster mitigation. This study aims to explain the gaps in forest fire disaster management in Indonesia, which have not maximized the results of observations from physical land and weather conditions as a basis for making decisions for more preventive forest fire mitigation.

\section{Research Methods}

This research is descriptive qualitative research with data collection techniques such as literature review, observation, and documentation. The literature review was conducted on several scientific articles on forest fire management. Through a literature review conducted on the paradigm of forest fire management in Canada, such as Tymstra et al. (2020), this study analyzes how strategies and policies by utilizing observations of weather conditions and physical land can play an essential role in the concept of forest fire disaster mitigation. As previously explained, Canada is an example of a country that has succeeded in changing the paradigm of early detection of forest fires through physical observations of land as an indicator of disaster preparedness (de Groot et al., 2015; McFayden et al., 2020; Gaur et al., 2021). A comparison of forest fire disaster management in Indonesia is carried out with reference to other related studies. By documenting several policies and regulations in Indonesia related to forest fires, an analysis of the opportunities for improving forest fire disaster mitigation is formulated in this study descriptively. Through the documentation of several regulations and policies related to forest fires in Indonesia, this study describes the gaps that exist in the concept of forest fire disaster mitigation. The analysis of the existing gaps is supported by a literature review of many studies related to forest fires on peatlands, synthesized to build conclusions in improving forest fire disaster mitigation in Indonesia.

\section{Results and Discussions}

\section{Forest Fire Management in Canada}

Based on data from the Canadian Interagency Forest Fire Center (CIFFC), one of the drivers of deforestation in Canada is the forest fires factor, which burned an average of 2.25 million hectares in 1970-2017. The Canadian forest area burned varied from 289,000 Ha in 1978 to 7.56 million Ha in 1989. Responding to the challenges of forest fires, the Canadian government developed policies and strategies that put forward the paradigm of preventive disaster management through various instruments. The visualization of forest fire data shown in Figure 1 shows that there is a tendency for forest fires in Canada to experience a decline.

Research conducted by Tymstra et al. (2020) describes the current state of forest fire management in Canada and discusses the challenges and opportunities of relevant agencies to address potential future fires. In the context of emergency management, Canada adopted an all-hazard approach to managing natural and human-induced disasters, including forest fires. The Canadian government in 2003 established Public Safety Canada, which is tasked with coordinating nationally across federal agencies to implement the disaster management approach. Each province and territory in Canada has a dedicated forest fire management agency as part of the Canadian Interagency Forest Fire Center (CIFFC). These agencies have to determine the resources needed every day to overcome the estimated condition of forest fires based on various outputs from the CFFDRS subsystem (CFFDRS) expressed in the preparedness level as in Table 1. In response to the 
preparedness status determined on a local scale, CIFFC will assess national preparedness (Table 2) by considering resource availability and using a decision criteria tree. The level of national preparedness determines the scale of forest fire suppression activities.

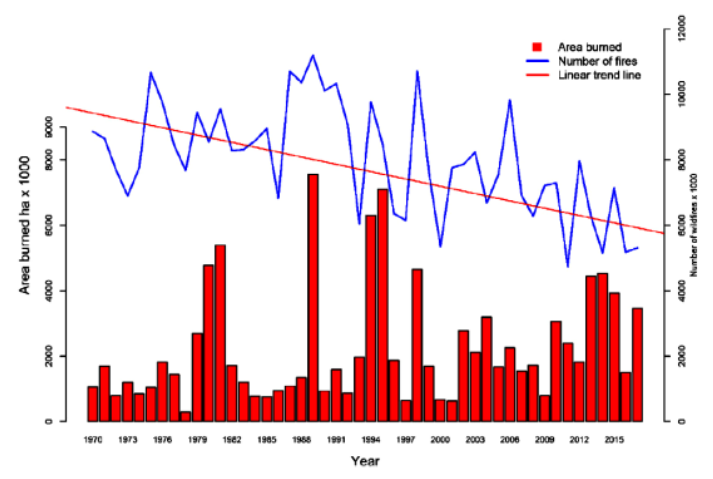

Source: Tymstra et al., 2020

Figure 1. Trends of Wildfires in Canada 1970-2017

Table 1. Level of Preparedness of Local Agencies Reported to CIFFC Regarding Forest Fire Mitigation in Canada

\begin{tabular}{lccccc}
\hline \multicolumn{1}{c}{ Criteria } & Level 1 & Level 2 & Level 3 & Level 4 & Level 5 \\
\hline $\begin{array}{l}\text { Agency fire } \\
\text { hazard }\end{array}$ & Low & Low-mod & Mod-high & High-extreme & Extreme \\
$\begin{array}{l}\text { Current fire load } \\
\text { Low }\end{array}$ & Low-mod & Mod-high & High & High-extreme \\
$\begin{array}{l}\text { Anticipated load } \\
\text { (7 days) }\end{array}$ & Low & Moderate & High & High-heavy & Heavy \\
$\begin{array}{l}\text { Agency resource } \\
\text { level }\end{array}$ & Adequate & Adequate & Some & Assistance & Inadequate \\
$\begin{array}{l}\text { CIFFC request for } \\
\text { mutual aid } \\
\text { response level }\end{array}$ & Excellent & Good & Mod-poor & Poor-nil & Nil \\
$\begin{array}{l}\text { Potential for } \\
\text { international } \\
\text { assistance }\end{array}$ & Nil & Nil & Nil & Increasing & Consideration \\
\hline
\end{tabular}

Source: Tymstra et.al., 2020

In managing forest fires, if each province and territory cannot manage further the fires that occur, it will impact the establishment of emergency status. The status of emergency for forest fires also marks the obligation of the federal government to start helping organize and manage forest fires that occur through Public Safety Canada's role as coordinator. The Canadian federal government's policy that requires every province and territory to prepare for handling forest fires in their respective regions has succeeded in making each agency at the regional/local scale use a risk-based approach. On a national scale, the Federal Department of Natural Resources routinely monitors potential forest fires 
to provide early warning to provincial governments through CIFFC (McFayden et al., 2020; Tymstra et al., 2020).

Table 2. National Level of Preparedness Used by CIFFC Regarding Forest Fire Mitigation in Canada

\begin{tabular}{|c|c|c|c|c|c|}
\hline Criteria & Level 1 & Level 2 & Level 3 & Level 4 & Level 5 \\
\hline $\begin{array}{l}\text { Significant } \\
\text { wildland fire } \\
\text { activity }\end{array}$ & Little or none & $\begin{array}{c}\text { Increasing in } \\
\text { a few } \\
\text { agencies }\end{array}$ & $\begin{array}{l}\text { One or more } \\
\text { agencies with } \\
\text { Incidents } \\
\text { Management } \\
\text { Teams } \\
\text { engaged }\end{array}$ & $\begin{array}{l}\text { Two or more } \\
\text { agencies with } \\
\text { Incidents } \\
\text { Management } \\
\text { Teams } \\
\text { engaged }\end{array}$ & $\begin{array}{l}\text { Two or more } \\
\text { agencies with } \\
\text { Incidents } \\
\text { Management } \\
\text { Teams } \\
\text { engaged }\end{array}$ \\
\hline $\begin{array}{l}\text { Resource demand } \\
\text { and mobilization }\end{array}$ & Low & Low-mod & Mod-high & High & Extreme \\
\hline $\begin{array}{l}\text { Potential for } \\
\text { emerging } \\
\text { significant } \\
\text { wildland fires }\end{array}$ & Minimal & Normal & Normal & High-extreme & High-extreme \\
\hline
\end{tabular}

Monitoring the potential for forest fires is the responsibility of CIFFC to forward it to each agency in each province and territory in Canada so that each region can prepare all needs (allocation of human resources, funds, and strategies) for preparedness in disaster mitigation. Forest fires. In its implementation, CIFFC also determines various levels of disaster status (Table 2) to facilitate the justification of mitigation actions that must be carried out, whether they can be handled independently by each province or need further assistance from the national level. Agencies in each province are given the authority to prevent and manage forest fires caused by humans through various actions, regulations, policies, and operating procedures. Regulations in Canada allow local fire-related agencies to issue permits such as fire warnings, restrictions, forest area closures, and the operation of off-road equipment or vehicle restrictions that have the potential to exacerbate forest fires. In addition, a binding forest fire control agreement was made between the government and the industry that carries out activities in the forest. This also includes requirements to help prevent and manage forest fires. Each province has the flexibility to issue policies related to forest fire prevention. For example, in the province of Alberta, to protect its protected forest area, the local government has imposed restrictions on the lighting of bonfires and fireworks during periods of fire proneness. Even in extreme situations, forest areas in the area are closed to the public. Sanctions are given strictly to violators who are handed over to the federal party (Tymstra et al., 2020).

The success of forest fire disaster management in Canada cannot be separated from the scientific basis used in assessing forest fire risk. The use of the Canadian Forest Fire Danger Rating System (CFFDRS) product, which considers various physical aspects such as weather, land conditions, and historical fire spread behavior, has helped a lot in improving forest fire preparedness in Canada. Systems such as CFFDRS are considered capable of providing a basis for understanding the fire environment and obtaining early warnings about potential forest fire events (Stocks et al., 1989; Taylor \& Alexander, 2006; de Groot et al., 2015).

Before being adopted by many countries to assess the risk of forest fires, the CFFDRS has undergone various developments, especially in the scientific aspect. It is now transformed into an index with a reasonably comprehensive scientific basis for forest fire disaster mitigation. The CFFDRS was first released as a reference in determining the potential for forest fires in 1969. In principle, the CFFDRS combines the threshold values of 
each sub-index to determine the behavior of forest fires. In summary, the sub-index used in formulating the CFFDRS consists of the results of calculations of weather variables and physical land conditions that affect the potential and spread of fire in forest fires. The subindices used in the CFFDRS are Fine Fuel Moisture Code (FFMC), Duff Moisture Code (DMC), Drought Code (DC), Initial Spread Index (ISI), Build Up Index (BUI), and Fire Weather Index (FWI), each of which represents a threshold value for fire behavior in forest fires (Lee et al., 2002; Gaur et al., 2021).

\section{Forest Fire in Indonesia and Peat Smoldering Phenomena}

A case study in the study of Tymstra et al. (2020) explains that natural factors mainly cause forest fires in Canada. Meanwhile, it has been widely stated that forest fire in Indonesia is also influenced by human factors such as land clearing activities by burning (Purnomo et al., 2017; Irfan et al., 2020; Jefferson et al., 2020). Even though the main factors causing fires in the two countries are different, the paradigm of forest fire disaster mitigation based on scientific assessment of physical variables in the form of CFFDRS in Canada can be followed to develop mitigation of forest fires in Indonesia. Early detection of forest fire disasters such as the one in Canada has a high chance of being adopted in other countries, especially in aligning it into policies or regulations. Tymstra et al. (2020) emphasize that forest fire preparedness is urgently needed to prioritize preventive elements in handling forest fire disasters.

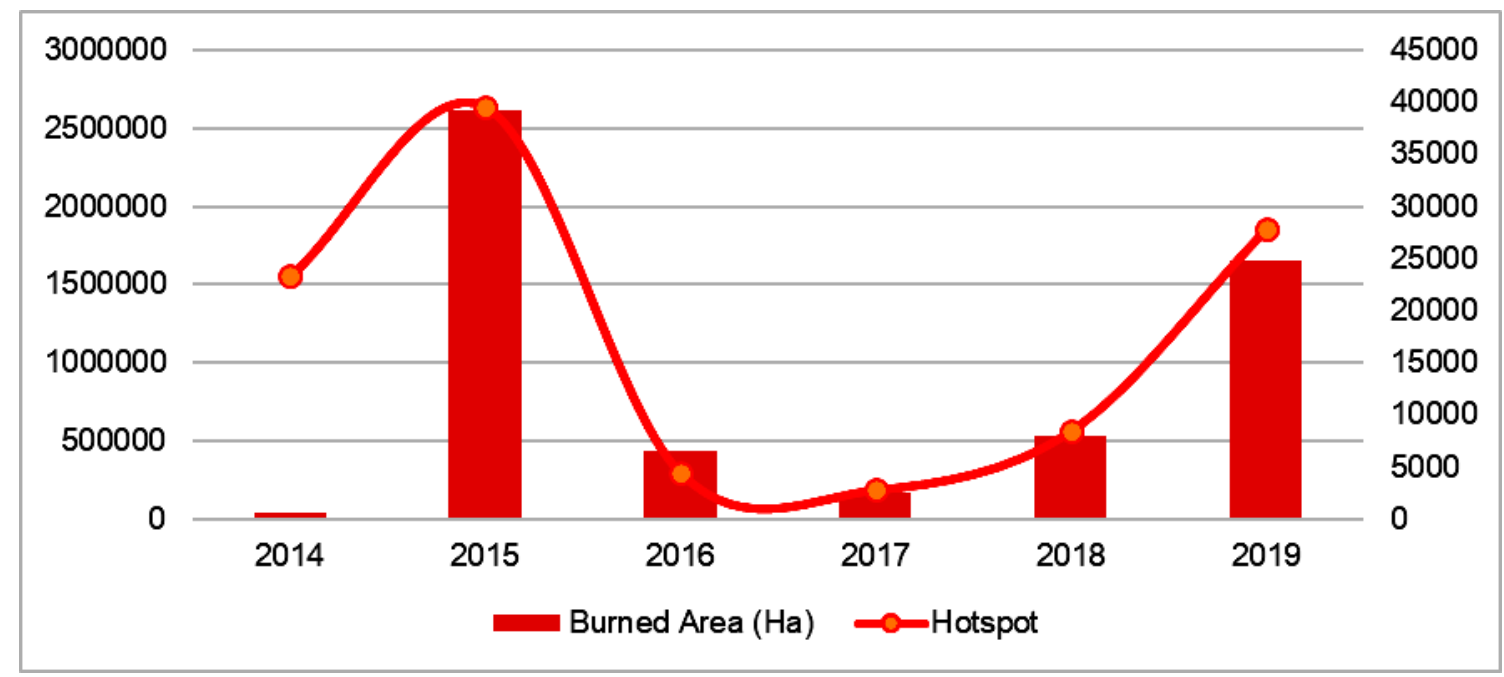

Source: SIPONGI KLHK, 2021

Figure 2. Burned Area and Number of Hotspots (2014-2019)

Similar to Canada, forest fires in Indonesia are also one of the driving factors in deforestation. Referring to the Ministry of Environment and Forestry (KLHK) data, forest fires in Indonesia in the 2014-2020 period have burned at least 5.7 million hectares of forest and land areas. In the last decade, the two most severe forest fires occurred in 2015 and 2019, with an area of 2.5 million and 1.5 million hectares of land burned (Figure 2). The forest fires that have spread to a more extensive area will undoubtedly be detrimental not only materially but also to environmental losses, especially in the destruction of forest ecosystems. On a national scale, the National Disaster Management Authority (BNPB), regarding the World Bank, estimates that losses due to forest and land fires in 2019 reached IDR 75 Trillion (Mongabay, 2019). 
The forest fires that 'routinely' occur in Indonesia indicate that the problem has not been appropriately resolved. The majority of forest fires always occur in provinces with peatland cover on the islands of Sumatra and Kalimantan. Forest fires that keep recurring make forest fires in Indonesia a significant threat in releasing carbon into the atmosphere, which can further trigger global climate change. Deforestation and the burning of peat forests contribute to $15 \%$ of the world's greenhouse gas emissions. As one of the largest tropical forest countries globally, Indonesia has removed 1.13 hectares of forest every year (2009-2013 period) or the equivalent of 3 times the size of a football field per minute. While there is good news with deforestation rates decreasing, the numbers are still high. This states deforestation and peat burning to be the leading causes of greenhouse gas emissions in Indonesia (Palmer, 2001; Austin et al., 2019). According to Dargie et al. (2017), peat ecosystems play an important role in ecology and are estimated to store carbon stocks of 104.7 gigatons. Uda et al. (2017) also emphasized that peatlands also have an economic function in addition to environmental value. The area of peatlands in Southeast Asia is a huge asset, Page et al. (2011) stated that with an area of $247,778 \mathrm{~km}^{2}$, peatlands in Southeast Asia store about 68.5 gigatons. However, forest fires have caused a significant decrease in peatland in Southeast Asia, including Indonesia. Miettinen et al. (2016) stated that one of the causes of the drastic decrease in peatland area was the forest fires. In previous another study, Miettinen \& Liew (2010) also identified the main cause of fires on peatlands in Sumatra and Kalimantan, especially land clearing for industrial plantation forests (HTI). Several other studies have also identified that in addition to natural factors, the role of humans individually and collectively also plays a role in the incidence of forest and land fires in Indonesia (Purnomo et al., 2017; Irfan et al., 2020).

Fires that occur on peatlands have the potential to be difficult to extinguish due to the phenomenon of peat smoldering. Cochrane (2015) explained that the phenomenon of peat fire/peat smoldering is a fire in peatland that can occur below the surface, so that fire propagation is very difficult to detect. This opinion was further elaborated by Rein (2016), who explained that peat smoldering is combustion that occurs in a slow porous fuel, low temperature, without fire on the surface, and the most persistent type of combustion phenomenon. On peatlands, according to Wilkinson et al. (2018), fires that occur on the surface can easily ignite fires in deeper layers of more than $50 \mathrm{~cm}$; this happens because of the influence of the level of wetness of the peatlands. Goldstein et al. (2020) also explained that the dryness of peatlands both on the surface and in the deeper layers is very influential in the phenomenon of peat smoldering. Several scientific findings regarding the characteristics of forest fires in Indonesia, especially on peatlands, should be able to encourage mitigation efforts by making more use of physical observations as an indicator of preparedness as was done in Canada through the CFFDRS system.

\section{Identification of Policies and The Opportunities for Improving Forest Fire Mitigation in Indonesia}

The Indonesian government already has several regulations related to controlling forest fires. Several legal guidelines regulate and explain policies and strategies in handling natural disasters in Indonesia, including forest fires (Table 3). By identifying the Indonesian government's policies and strategies concerning forest fires, it can generally be concluded that managing forest fires in Indonesia has involved many parties, from the central government to the regions. However, the management of forest fires in Indonesia has not fully prioritized the preventive principle. Forest and land fires, which still occur every year, only get great attention when they reach their peak, usually marked by the dense smog that disrupts people's lives in the affected areas. The importance of disaster management for forest fires, as explained by Wibowo (2019), is needed because there are at least three factors that affect the poor management of forest and land fires in Indonesia: the lack of prevention-oriented technological innovations, the complexity of coordination between 
institutions, and the limited infrastructure that is oriented towards prevention, and community economic empowerment.

Table 3. Regulations and Policies Related to Forest Fire Management in Indonesia

\begin{tabular}{ll}
\hline \multicolumn{1}{c}{ Regulations/Policies } & \multicolumn{1}{c}{ Remarks } \\
\hline UU/Constitution 23/1997 & $\begin{array}{l}\text { Regulates the obligation of everyone to maintain environmental } \\
\text { sustainability and prevent and overcome environmental } \\
\text { pollution and destruction. }\end{array}$
\end{tabular}

UU 41/1999 Forestry

PP 4/1999 The Control of Environmental Damage and Pollution

PP 45/2004 Forest Protection

UU 18/2004 Plantations

UU 19/2004 Forestry

UU 32/2009 Environmental

Processing

PP 21/2008 The Implementation of Disaster Management

Inpres/Presidential Instruction $11 / 2015$

Perka BNPB 10/2008 Guidelines for Disaster Emergency Response Command

PP 71/2014 The Protection and Management of Peat Ecosystems

Permen LHK

P.32/MenLHK/Setjen/Kum.1/2/2016 on Forest and Land Fire Control
Article 50 paragraph (3), explains that forest burning is subject to a maximum imprisonment of 15 years and/or a maximum fine of IDR 15 billion.

Prohibition on forest and land burning, however, the prohibition is only subject to administrative sanctions.

Article 10 paragraph (2) letter (b), stipulates that forest protection activities include prevention, suppression and handling of fire impacts.

Obligation for plantation industries to preserve environmental functions.

Explains the principle that forest burning is prohibited.

Regulates criminal provisions for people who burn the environment

It is explained in article 21 that the authority to administer disaster management in emergency response situations is the responsibility of the National Disaster Management Authority (BNPB).

Instructs institutional and regional leaders to improve the control of forest fires through prevention, suppression and postfires management.

Explains the stages of determining disaster status and the flow of command for disaster management.

E,xplains that to define a damaged peat ecosystem one can refer to the groundwater table which is more than $0.4 \mathrm{~m}$ below the peat surface.

Explains the responsibilities of forest and land fire control organizations at the national, provincial, and city/district levels.

Carter (2008) describes the disaster management cycle as illustrated in Figure 3. In the concept of disaster management, pre-disaster conditions, which include prevention, mitigation, and preparedness, are a series that determine how much impact a disaster will have. Sandhyavitri et al. (2015) also emphasize that early warning based on weather 
parameters and field land will be the key to proper disaster mitigation. In another study, Syaufina (2018) emphasizes that there is a need to increase awareness of peatland management, especially in mitigating forest and land fires, one of which can be achieved by analyzing the potential for fire occurrence, as implemented in Canada through CFFDRS.

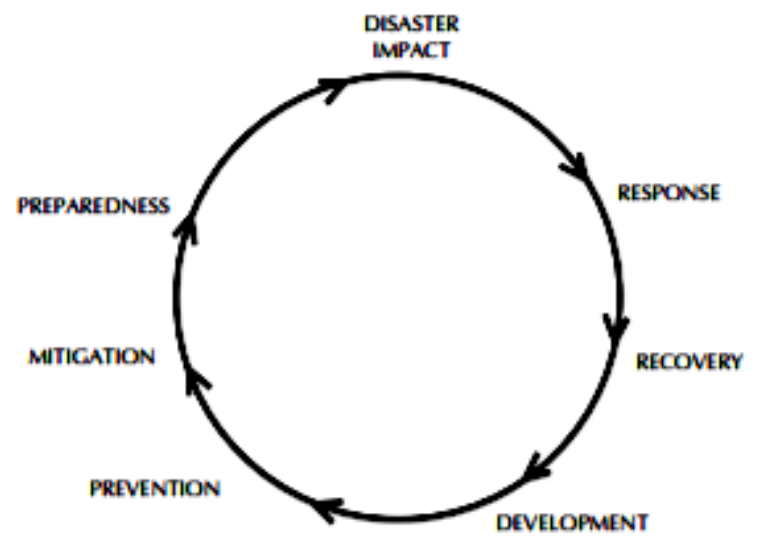

Source: Carter, 2008

Figure 3. Disaster Management Cycle

Although the identification of the level of vulnerability to forest fires such as the CFFDRS has now begun to be adopted in Indonesia to state the potential for fires, there are gaps in its implementation into regulations that are the basis for organizing forest fire disaster management activities in Indonesia. For example, in determining the status of a disaster as described in Perka BNPB 10/2008, national-scale suppression will only be carried out if the status of 'Emergency Response' has been determined through a request from the local government (Governor) to the disaster center command (BNPB). It means that local governments are responsible for determining the criteria used in determining the status of 'Emergency Response.'. An example for determining the status of 'Emergency Response' for forest fires in Riau Province (Pergub Riau 9/2020) shows that so far, the references used in determining disaster status still refer to the conditions and variable values where the peak of the dry season occurs as mentioned in Table 4.

Table 4. Examples of the Use of Physical Variables Used in Determining the Emergency Response Status of Forest Fires in Riau Province

\begin{tabular}{ll}
\hline \multicolumn{1}{c}{ Variables } & \multicolumn{1}{c}{ Values Threshold } \\
\hline Air Temperature & Extreme condition $\left(\geq 36^{\circ} \mathrm{C}\right)$ \\
Standardizied Precipitation Index (SPI) & Very Dry condition \\
Cummulative Days Without Rain & $21-30$ days \\
Air Pollution Standard Index (ISPU) & $\geq 300$ \\
Number of Hotspots & There is no definite mention of the number of \\
& hotspots, only a descriptive explanation of the \\
& increasing number of hotspots. \\
Visibility due to Smoke Haze & In a state of interfering the transportation. \\
\hline
\end{tabular}

Source: Government of Riau Province, 2020 


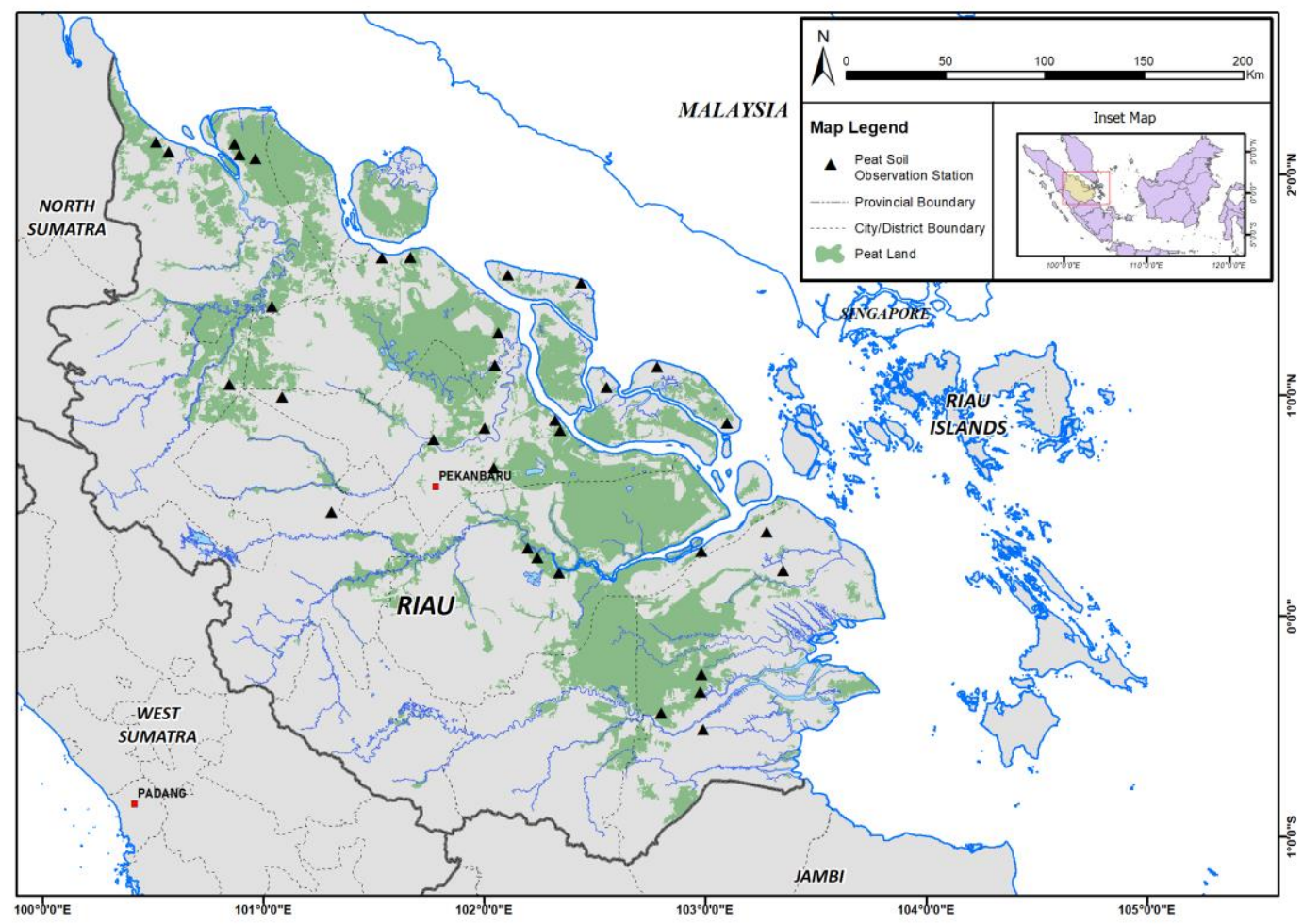

\section{Figure 4. Spatial Distribution of Peatland Observation Stations SIPALAGA (as symbolized by Black Triangle)}

The suppression of forest fires carried out at the peak of the dry season will encounter various natural obstacles such as hydrometeorological factors so that the operations to manage the suppression of forest fires carried out by the government seem delayed. Adopting an analysis for early detection such as FDRS will help optimize fire suppression and control strategies to reduce the expansion of forest fires potentially. Burns (2016) explains that one approach to sustainable environmental management is applying sustainable technological innovations. Lesson from Canada in terms of early detection to find out the potential for forest fires through the CFFDRS requires various resources, one of which is an instrument for monitoring and observation in vulnerable areas due to forest fires. Through the Peatland Restoration and Mangrove Rehabilitation Agency (BRGM) since 2018, The Government of Indonesia has prepared a physical monitoring system for peatlands (SIPALAGA) that conducts real-time observations in several provinces prone to forest fires. As an example of the application of the SIPALAGA instrument for monitoring the physical condition of peatlands in Riau Province, at least 33 SIPALAGA instrument units can provide peatland monitoring values to support decisions in determining the disaster status of forest and land fires, as shown in Figure 4. Early detection of the danger of forest fires in Riau Province could be more comprehensive by combining the results of observations of atmospheric parameters such as rainfall and the number of days without rain. Thus, the application of SIPALAGA can be more mainstreamed to support decisionmaking in determining disaster status so that it can provide improvements to the paradigm of forest fire disaster mitigation that often occurs in Riau Province.

The importance of a complete disaster management paradigm, starting from assessing the potential to rehabilitation related to forest fires, can be supported by various 
technologies at their respective stages and portions. By adopting analyses for early detection such from monitoring the physical condition of peatlands will assist in optimizing fire suppression and control strategies to potentially reduce the expansion of forest fires. The use of such observations should serve as a scientific basis for the early detection of forest fire disasters. The results of monitoring the physical condition of peatlands can be an essential input in the context of strengthening the mitigation of forest and land fires in Indonesia.

\section{Conclusion}

The forest fire disaster mitigation paradigm in Canada provides lessons that observation and monitoring of parameters that cause forest fires can contribute to mainstreaming a more preventive forest fire suppression approach. For example, observations of weather and soil physical parameters can be used to help determine the potential for forest fires, so that forest fire prevention strategies can prioritize the principle of prevention before the fire spreads and burns a more extensive forest area. In that way, preparedness can be improved through a scientific basis from observing the physical condition of the influential variables so that it will assist in achieving effective and efficient forest fire mitigation.

The results of the analysis of the risk of forest and land fires such as the CFFDRS can be implemented to formulate policies related to managing forest fires. Currently, policies in determining the status of disaster at the regional level in Indonesia require a paradigm shift to consider using monitoring and analysis of the potential for forest fires. By determining the status of a disaster that considers the potential for fires, the government's response to forest fires is expected to change from being reactive to being more preventive. Furthermore, by using a comprehensive scientific reference from several variables regarding the potential level of forest fires as input in the decision-making process, managing forest fires on a national scale can be more timely and effective to extinguish or limit the potential spread of forest fires. Indonesia's forest fire has its own complexity, involving environmental, social, and economic aspects. For this reason, other efforts that are no less important in reducing forest and land fires, such as law enforcement to strict regulations regarding regional functions, also need to be continuously improved.

\section{References}

Austin, K. G., Schwantes, A., Gu, Y., \& Kasibhatla, P. S. (2019). What causes deforestation in Indonesia? Environmental Research Letters, 14(2). doi:10.1088/1748-9326/aaf6db.

Burns, T. R. (2016). Sustainable development: Agents, systems and the environment. Current Sociology, 64(6), 875-906. doi:10.1177/0011392115600737.

Carter, W. N. (2008). Disaster management: A disaster manager's handbook. Asian Development bank.

Cochrane, M. (2015). Above and belowground tropical rainforest fire dynamics. Geographic Information Science Center of Excellence (GIScCE) South Dakota State University.

Dargie, G. C., Lewis, S. L., Lawson, I. T., Mitchard, E. T. A., Page, S. E., Bocko, Y. E., \& Ifo, S. A. (2017). Age, extent and carbon storage of the central Congo Basin peatland complex. Nature, 542, 86-90. doi:10.1038/nature21048.

de Groot, W. J., Wotton, B. M., \& Flannigan, M. D. (2015). Wildland fire danger rating and early warning systems. In Wildfire Hazards, Risks, and Disasters (pp. 207-228). doi: 10.1016/B978-0-12-410434-1.000117.

Faturahman, B. M. (2017). Reformasi administrasi dalam manajemen bencana. Mimbar Yustitia, 1(2), 185-201. doi:10.52166/mimbar.v1i2.1109. 
Field, R. D., Van Der Werf, G. R., Fanin, T., Fetzer, E. J., Fuller, R., Jethva, H., Levy, R., Livesey, N. J., Luo, M., Torres, O., \& Worden, H. M. (2016). Indonesian fire activity and smoke pollution in 2015 show persistent nonlinear sensitivity to El Niño-induced drought. Proceedings of the National Academy of Sciences of the United States of America, 113(33), 9204-9209. doi:10.1073/pnas.1524888113.

Gaur, A., Bénichou, N., Armstrong, M., \& Hill, F. (2021). Potential future changes in wildfire weather and behavior around 11 Canadian cities. Urban Climate, 35. doi:10.1016/j.uclim.2020.100735.

Goldstein, J. ., Graham, L., Ansori, S., Vetrita, Y., Thomas, A., Applegate, G., \& Cochrane, M. A. (2020). Beyond slash-and-burn: The roles of human activities, altered hydrology and fuels in peat fires in Central Kalimantan, Indonesia. Singapore Journal of Tropical Geography, 41(2), 190-208. doi:10.1111/sjtg.12319.

Government of Riau Province. (2020). Peraturan Gubernur Riau Nomor 9 Tahun 2020 tentang prosedur tetap kriteria penetapan status keadaan darurat bencana dan komando satuan tugas pengendalian kebakaran hutan dan lahan di Provinsi Riau. Riau Province.

Huijnen, V., Wooster, M. J., Kaiser, J. W., Gaveau, D. L. A., Flemming, J., Parrington, M., Inness, A., Murdiyarso, D., Main, B., \& Van Weele, M. (2016). Fire carbon emissions over maritime southeast Asia in 2015 largest since 1997. Scientific Reports, 6, 1-8. doi:10.1038/srep26886.

Irfan, A., Febria, D., Nofianti, L., \& Rijulvita, S. (2020). The conceptual framework for Water accounting in sustainability of peatland ecosystems. An islamic perspective. Journal of Environmental Management and Tourism, 11(3), 589-593. doi:10.14505/jemt.v11.3(43).11.

Jefferson, U., Carmenta, R., Daeli, W., \& Phelps, J. (2020). Characterising policy responses to complex socioecological problems: 60 fire management interventions in Indonesian peatlands. Global Environmental Change, 60. doi:10.1016/j.gloenvcha.2019.102027.

Lee, B. S., Alexander, M. E., Hawkes, B. C., Lynham, T. J., Stocks, B. J., \& Englefield, P. (2002). Information systems in support of wildland fire management decision making in Canada. Computers and Electronics in Agriculture, 37(1-3), 185-198. doi:10.1016/S0168-1699(02)00120-5.

McFayden, C. B., Woolford, D. G., Stacey, A., Boychuk, D., Johnston, J. M., Wheatley, M. J., \& Martell, D. L. (2020). Risk assessment for wildland fire aerial detection patrol route planning in Ontario, Canada. International Journal of Wildland Fire, 29(1), 28-41. doi:10.1071/WF19084.

Miettinen, J., \& Liew, S. C. (2010). Status of peatland degradation and development in Sumatra and Kalimantan. Ambio, 39(5), 394-401. doi:10.1007/s13280-010-0051-2.

Miettinen, J., Shi, C., \& Liew, S. C. (2016). Land cover distribution in the peatlands of Peninsular Malaysia, Sumatra and Borneo in 2015 with changes since 1990. Global Ecology and Conservation, 6, 67-78. doi:10.1016/j.gecco.2016.02.004.

Mongabay. (2019). Bank dunia: Kerugian Indonesia dampak karhutla 2019 capai Rp72,95 triliun. Retrieved from: https://www.mongabay.co.id/2019/12/16/bank-dunia-kerugian-indonesia-dampak-karhutla2019-capai-rp7295-triliun/.

Page, S. E., Rieley, J. O., \& Banks, C. J. (2011). Global and regional importance of the tropical peatland carbon pool. Global Change Biology, 17(2), 798-818. doi:10.1111/j.1365-2486.2010.02279.x.

Palmer, C. E. (2001). The extent and causes of illegal logging: An analysis of a major cause of tropical deforestation in Indonesia. CSERGE Working Paper, January 2001, 33. Retrieved from: http://www.cserge.ucl.ac.uk/Illegal_Logging.pdf.

Purnomo, H., Shantiko, B., Sitorus, S., Gunawan, H., Achdiawan, R., Kartodihardjo, H., \& Dewayani, A. A. (2017). Fire economy and actor network of forest and land fires in Indonesia. Forest Policy and Economics, 78, 21-31. doi:10.1016/j.forpol.2017.01.001.

Rein, G. (2016). The S.F.P.E. handbook of fire protection engineering. In Fire Safety Journal. Springer. doi:10.1007/978-1-4939-2565-0.

Sandhyavitri, A., Fauzi, M., Gunawan, H., Sutikno, S., Amri, R., Siswanto, Suryawan, I., Mukti, M. A., \& Riza, S. (2015). Mitigasi bencana banjir dan kebakaran. UR Press.

Stocks, B. J., Lawson, B. D., Alexander, M. E., Van Wagner, C. E., McAlpine, R. S., Lynham, T. J., \& Dube, D. E. (1989). Canadian forest fire danger rating system: An overview. The Forestry Chronicle, 65(4), 258-265.

Syaufina, L. (2018). Forest and land fires in Indonesia: Assessment and mitigation. In Integrating Disaster Science and Management: Global Case Studies in Mitigation and Recovery (pp. 109-121). Elsevier Inc. doi:10.1016/B978-0-12-812056-9.00008-7. 
Taufik, M., Veldhuizen, A. A., Wösten, J. H. M., \& van Lanen, H. A. J. (2019). Exploration of the importance of physical properties of Indonesian peatlands to assess critical groundwater table depths, associated drought and fire hazard. Geoderma, 347, 160-169. doi:10.1016/j.geoderma.2019.04.001.

Taylor, S. W., \& Alexander, M. E. (2006). Science, technology, and human factors in fire danger rating: The Canadian experience. International Journal of Wildland Fire, 15(1), 121-135. doi:10.1071/WF05021.

Tymstra, C., Stocks, B. J., Cai, X., \& Flannigan, M. D. (2020). Progress in disaster science wild fire management in Canada: Review, challenges and opportunities. Progress in Disaster Science, 5. doi:10.1016/j.pdisas.2019.100045.

Uda, S. K., Hein, L., \& Sumarga, E. (2017). Towards sustainable management of Indonesian tropical peatlands. Wetlands Ecology and Management, 25(6), 683-701. doi:10.1007/s11273-017-9544-0.

Wibowo, K. A. (2019). Manajemen penanganan kebakaran hutan dan lahan (karhutla) guna peningkatan ekonomi kerakyatan. Jurnal Studi Sosial dan Politik, 3(1), 69-83. doi:10.19109/jssp.v3i1.4072.

Wilkinson, S. L., Moore, P. A., Flannigan, M. D., Wotton, B. M., \& Waddington, J. M. (2018). Did enhanced afforestation cause high severity peat burn in the Fort McMurray Horse River wildfire? Environmental Research Letters, 13(1). 